\title{
Open access indicators and information society: the Latin American case
}

\author{
Nancy Gómez \\ E-lis: E-prints in Library and Information Science, Santiago, Chile \\ Atilio Bustos Gonzalez \\ Pontific Catholic University of Valparaiso, Valparaiso, Chile \\ Julio Santillan Aldana \\ Documentation Center, Bartolome de Las Casas Institute, Lima, Peru, and \\ Olga Arias \\ Luis Federico Leloir Library, University of Buenos Aires, \\ Buenos Aires, Argentina
}

\begin{abstract}
Purpose The purpose of this paper is to estimate open access penetration ratios through cross analysis of existing social context and open access indicators in Latin America.

Design/methodology/approach The following parameters were used to characterize the chosen countries. On one hand, it takes social context indicators like digital opportunity index (DOI), GDP 2007 (Organization for Economic Co operation and Development) (www.oecd.org/home/0,3305,e n 264920118511111 1,00.html), scientific output 2005, and investment in science and technology vs GDP 2004. On the other hand, it analyses open access indicators considering the two main open access strategies the green and gold routes and the existing legal framework.

Findings This paper discusses the evolution of DOI and compares with open access parameters (numbers of repositories, number of registries in repositories, DOAJ journals and number of creative commons licences) in the context of scientific information in developing countries in Latin America.

Research limitations/implications This paper is not an exhaustive survey and limits the comparison to the Latin American Countries, focalized in Brazil, Chile and Argentina.

Originality/value This paper gives an overview of the situation of three particular countries: Brazil, Chile and Argentina, and explains the position of these countries in the open access movement in Latin America.
\end{abstract}

Keywords Information society, Open systems, Communication technologies, South America

Paper type Viewpoint

\section{Introduction}

The internet has created unprecedented possibilities to disseminate, share and build on the outcome of research efforts. Developing countries face major challenges in terms of research infrastructure, mainly due to high levels of poverty and unequal wealth and income distribution. This has a direct influence on informational literacy rates, and other indicators of the information society, which have led to the coining of the term 
"digital divide," meaning the difference in terms of access to information and communication technologies among developed and developing countries.

In World Summit on the Information Society (WSIS, 2006), an international conference held in two phases in 2003 and 2005 in Geneva and Tunis, respectively, world leaders from more than 174 countries (among them heads of governments, ministers, vice-ministers as well as high-level representatives from international organizations and private sector) committed to turning the digital divide into a digital opportunity for all, as one of the main objectives of the conference.

Developing countries face major economic problems, among them poverty, intense foreign debt and high illiteracy rates (Chan and Costa, 2004). Research infrastructure is also inadequate, which in turn leads to low levels of scientific output. Information is a key component in the production of new scientific knowledge, so that, in this sense, both information and communications technology (ICTs) technologies and access to quality research content are crucial.

The open access movement arose at the beginning of 2000 as a reaction against the traditional scientific publishing model. According to Suber's (2004-2006) definition, "open access (OA) literature is digital, online, free of charge, and free of most copyright and licensing restrictions." The BOAI (2005) defines it as follows:

By "open access" to this literature, we mean its free availability on the public Internet, permitting any users to read, download, copy, distribute, print, search, or link to the full texts of these articles, crawl them for indexing, pass them as data to software, or use them for any other lawful purpose, without financial, legal, or technical barriers other than those inseparable from gaining access to the internet itself. The only constraint on reproduction and distribution, and the only role for copyright in this domain, should be to give authors control over the integrity of their work and the right to be properly acknowledged and cited.

As Suber (2004-2006) points out "[...] campaign for OA focuses on literature that authors give to the world without expectation of payment". A strong argument in favor of open access is the concept of free access to publicly funded research, best set out on the (Organization for Economic Co-operation and Development - OECD, 2004) Declaration on Access to Research Data from Public Funding, signed in 2004 by over 30 countries.

There are two main strategies for attaining open access: publishing in an open access journal, known as "the gold route" or archiving in institutional archives or repositories, known as "the green route." The chief difference between them is that OA journals conduct peer review, whereas OA archives do not.

John Willbanks, Executive Director of BMJ and Leader of the Science Commons Project states that: "[...] Open access journals are entering the mainstream of scholarly publishing". The Directory of Open Access Journals (DOAJ) (www.doaj.org), a listing of "free, full text, quality controlled scientific and scholarly journals, includes 2478 journals, with on average more than one journal a day added in 2006." (Willbanks, 2006). As of this paper writing, the DOAJ lists 2,995 journals amounting to nearly 10 per cent of the whole scientific literature included in Ulrich Periodicals Directory (www.ulrichsweb.com/ulrichsweb/). In the same direction, the number of OA repositories is steadily growing. The Registry of Open Access Repositories (ROAR) (http://roar.eprints.org/) lists around 1,000. According to Willbanks (2006) ROAR has grown "[...] by nearly one every other day, and the number of records in those archives
Open access indicators 
OCLC

25,2

has grown by nearly 600 percent, to 1.2 million papers. Open access is here to stay, in one form or another."

\section{Context}

In order to carry out a survey of the Information Society situation, one must research institutional organizations in the region. Two different reports were analyzed, released, respectively, by the Information Society Observatory for Latin American and the Caribbean (OSILAC, Spanish acronym), under the framework of the Economic Commission for Latin America and the Caribbean (Spanish acronym: CEPAL), and the ITU/UNCTAD World Information Society Report 2007.

\section{The eLAC2007 report}

Since 2000, Governments in Latin America and the Caribbean have stated their commitment and worked towards the development of regional observatories to track the impact of ICTs on the economy, based on statistical data of the Information Society, issuing basic indicators. In this sense, OSILAC was assigned the mission of building indicators and monitoring the situation of eLAC 2007, the regional Plan on Information Society for Latin America and the Caribbean. The plan consists of 30 subject areas with 70 short-term activities, which contribute to the long-term implementation of the WSIS Global Action Plan, enshrined within the Millennium Development Goals (Observatorio para la Sociedad de la Información en América Latina y el Caribe, 2007).

This plan is structured around five critic areas identified by the countries in the region: access and digital inclusion, knowledge and capacity building, public efficiency and transparency, policy instruments and enabling environment. The activities within eLAC are aimed at reaching three main objectives:

(1) Fostering regional projects to reinforce initiatives and cooperation, to help develop common synergies.

(2) Promoting strategies to help getting measurable results in specific areas through the implementation of indicators on the development and progress of the information society.

(3) Deepening knowledge to better understand critical areas to support the definition, implementation and evaluation of policies.

The plan shows a significant progress throughout the region in the development of the information society: out of the 27 areas surveyed, 15 show progress, or even strong progress, whereas 12 remain with moderate or low progress levels. Table I depicts the level progress in each area.

The major progresses count among the two first areas: access and digital inclusion, and knowledge and capacity building, while public efficiency and policy instruments show less improvements.

Open access can be considered a transversal variable with a direct effect on a number of activities described in the table, especially in the two first areas, as explained below:

- 10 Education and research networks. Cooperación Latino Americana de Redes Avanzadas (CLARA) is a research network which connects 16 countries in Latin America, including universities and research centers, to encourage 


\begin{tabular}{|c|c|c|c|}
\hline Area & Aim & Progress level & pen access \\
\hline \multirow[t]{7}{*}{ A. Access and digital inclusion } & 1. Regional Infrastructure & Progress & \\
\hline & 2. Community centres & Strong progress & \\
\hline & 3. Online schools and libraries & Progress & \\
\hline & 4. Online health centers & No progress & \\
\hline & 5. Work & Moderate progress & \\
\hline & 6. Local governments & Strong progress & \\
\hline & 7. Alternative technologies & Moderate progress & \\
\hline \multirow[t]{7}{*}{ B. Knowledge and capacity building } & 8. Software & Moderate progress & \\
\hline & 9. Training & Progress & \\
\hline & 10. Education and research networks & Strong progress & \\
\hline & 11. Science and technology & No progress & \\
\hline & 12. Companies & Progress & \\
\hline & 13. Contents and creative industries & Progress & \\
\hline & 14. Internet governance & Progress & \\
\hline \multirow[t]{7}{*}{ C. Public transparency and efficiency } & 15. E government & Progress & \\
\hline & 16. E learning & Strong progress & \\
\hline & 17. E health & No progress & \\
\hline & 18. Catastrophes & No progress & \\
\hline & 19. E justice & Moderate progress & \\
\hline & 20. Environment protection & Moderate progress & \\
\hline & $\begin{array}{l}\text { 21. Public information and cultural } \\
\text { inheritage }\end{array}$ & Progress & \\
\hline \multirow[t]{5}{*}{ D. Political instruments } & 22. National strategies & Progress & \\
\hline & 23. Financing & No progress & \\
\hline & 24. Universal access policies & No progress & \\
\hline & 25. Legal framework & No progress & Table I. \\
\hline & 26. Measuring and indicators & Strong progress & eLAC2007 \\
\hline E. Enabling environment & 27. WSIS and eLAC follow up & Strong progress & progress levels \\
\hline
\end{tabular}

regional cooperation in scientific and educational activities (www.redclara.net/). The necessary infrastructure for building a network of institutional open access repositories could be provided by CLARA, since it includes the countries selected for this survey.

- 11 Science and technology. Most Latin America countries have a very low investment rate in research and development, being in average around 0.5 per cent of their gross domestic product (GDP), except for Brazil, first place in the region, with 1 per cent, but very far from those of developed countries. As Rossini states (Rossini, 2007): "[...] open access represents the best method for the flow, interchange and production of scientif knowledge - that access to knowledge is crucial for innovation and innovation is crucial for development."

- 16 E-learning. The main objective of e-learning is the creation and fostering of digital educational contents. The building of electronic theses databases in Brazil (Biblioteca Digital de Tesis) (http://bdtd.ibict.br/bdtd/) and Chile (Cybertesis) (www.cybertesis.net/), since the late 1990s, has led to significant progress in the field of e-learning. Higher education institutions rely heavily on this type of materials, that enables researchers and students to keep to date with cutting-edge scientific advances. 
OCLC

25,2

Figure 1.

DOI categories

- 17 E-health. Virtual libraries can take advantage of ICTs through greater connectivity with their partners in the region and worldwide. In addition to that, it is often not recognised that international medical and environmental research programmes may be inappropriate for developing countries, due to the lack of knowledge of research generated in them, where the major health problems exist. A search for "malaria" on the Bioline International web site illustrates the volume of relevant research available from the developing world (Chan and Costa, 2004).

\section{The World Information Society Report 2007: beyond WSIS}

The WSIS is a summit held in two phases in Geneva, in December 2003 and in Tunis, in November 2005 with the main objectives of building the information society and making advances towards bridging the digital divide. The World Information Society Report 2007: beyond WSIS (International Communication Union, 2007) is the second of a series of reports intended to track current implementation and progress in achieving the WSIS targets. It has been created by the Digital Opportunity Platform, an open multi-stakeholder platform with contributions from governments, academics and civil society, as well as inter-governmental organisations. As an evaluating tool, the digital opportunity index (DOI) has been created as a composite index comprising eleven separate indicators, grouped into three clusters of opportunity, infrastructure and utilization (Figure 1).

Indicators in various data series are standardized on a scale of zero to one, making the DOI simple and straightforward to calculate. In that way, access to and affordability of ICTs is condensed into a single index number, permitting comparison of countries scores in any one year, as well as over time.

This index has been chosen because it best represents the variability of a number of Latin American countries between 2004 and 2006. In that period, Chile, Argentina and Brazil appear in the first places, above the Latin American average growth of 3 per cent and close to the DOI variability worldwide. These three countries will face the challenge of tracking their progress within the Information Society, as well as the impact that open access movement has had in recent years (Figure 2).

\begin{tabular}{|ll|}
\hline 1 & Percentage of population covered by mobile cellular telephony \\
\hline 2 & Internet access tariffs as a percentage of per capita income \\
\hline 3 & Mobile cellular tariffs as a percentage of per capita income \\
\hline
\end{tabular}

4 Proportion of households with a fixed line telephone

5 Proportion of households with a computer

6 Proportion of households with internet access at home

7 Mobile cellular subscribers per 100 inhabitants

8 Mobile internet subscribers per 100 inhabitants

9 Proportion of individuals that used the internet

10 Ratio of fixed broadband subscribers to total internet subscribers 11 Ratio of mobile broadband subscribers to total mobile subscribers

Source: ITU/UNCTAD/KADO Digital Opportunity Platform
Oppurtunity

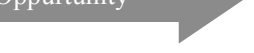

Infrastructure

Utilization

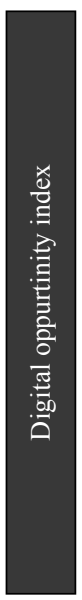




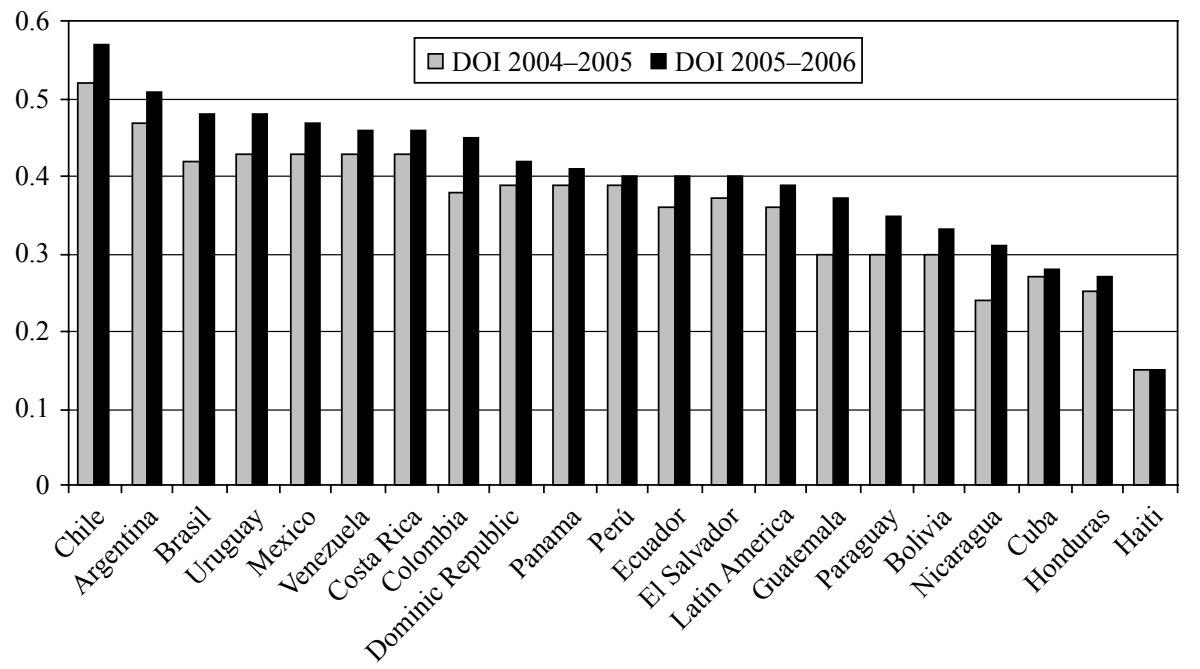

Open access indicators

Figure 2.

DOI evolution in Latin American

\section{Countries situation}

The following parameters were used to characterise the chosen countries:

- social context indicators;

- DOI;

- GDP 2007 (OECD) (www.oecd.org/home/0,3305,en 26492011851111 1,00. html);

- scientific output 2005 (Scimago Research Group) (www.scimago.es/); and

- investment in science and technology vs GDP 2004 (Table II).

Open access indicators

Considering the two main open access strategies - the green and gold routes - and the legal framework, the following parameters were analyzed:

- number of repositories in ROAR;

- number of registries in ROAR repositories;

- number of journals in DOAJ;

- number of journals in Scientific Electronic Library Online - SciELO (2007);

- number of journals in BIOLINE;

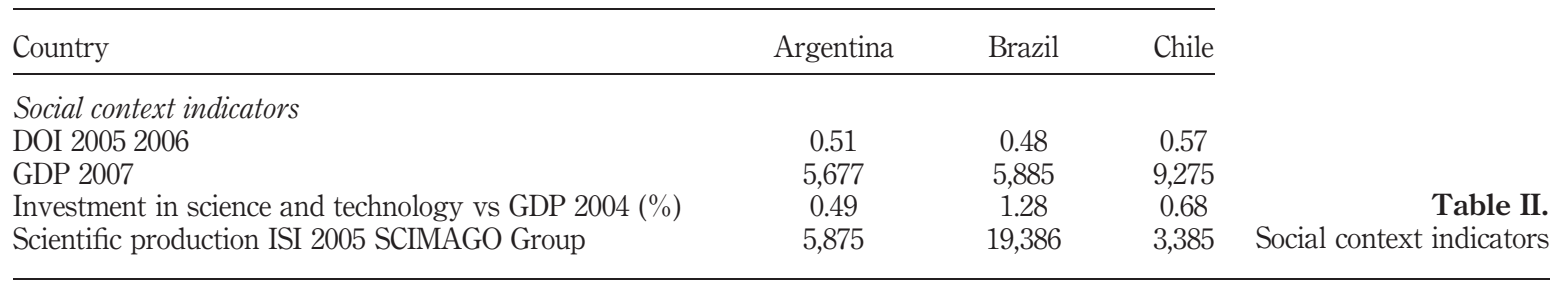


OCLC

25,2

- date of adoption of creative commons license; and

- number of creative commons licenses (Table III).

\section{Brazil}

From the three selected countries, Brazil has the lowest DOI. It was the first in the region to adapt creative commons licenses, and at present it is the country with the greatest number of granted licenses. Its scientific output is the highest in the region, with around 200,000 documents in 2005, closely related to the investment level in science and technology.

Sely Costa makes an exhaustive report (Costa, 2007; Costa and Kuramoto, 2007; Electronic Publishing Trust for Development, 2007) where she describes the multiple steps Brazil has taken to accomplish the goals of open access, since the SciELO platform was brought in as early as 1997. These steps include statements in favour of $\mathrm{OA}$, ways to implement OA initiatives, publications and courses. All these initiatives have been carried out mainly by the Instituto Brasileiro de Ciencia e Tecnologia (IBICT), which has had a leading role coordinating the Open Access Movement with SciELO, the Brazilian Parliament, the Brazilian Council of University Chancellors and other societies in Brazil, and in partnership with other countries. Some of these initiatives are:

- carrying out technology prospective studies;

- customizing software (OJS, OCS, Eprints, Dspace and NDLTD);

- training people (640 people from 189 institutions);

- transferring technology (SEER - open journal systems, SOAC - open conference system, Institutional and Discipline Repositories, mostly to universities);

- building portals - data and service providers (BDTD; Oasis.br);

- sensitising the scholarly community and policy makers; and

- expanding Brazilian initiatives to the Portuguese speaking ALemPLus project) and LA countries.

\begin{tabular}{lccc}
\hline Open access indicators & Argentina & Brazil & Chile \\
\hline $\begin{array}{l}\text { Gold route indicators } \\
\text { Number of repositories (ROAR) }\end{array}$ & 2 & 55 & \\
$\begin{array}{l}\text { Number of registries in repositories (ROAR) } \\
\text { Green route indicators }\end{array}$ & 2,143 & 346,411 & 11,610 \\
BIOLINE & & 4 & 2 \\
DOAJ Journals & 42 & 287 & 81 \\
SciELO (July 2007) & 29 & 185 & 66 \\
Legal framework open access & & & July 4 \\
$\begin{array}{l}\text { Adaptation of Creative Commons License to local } \\
\text { legislation }\end{array}$ & October 5 & & July 5 \\
$\begin{array}{l}\text { Number of Creative Commons Licences (Data } \\
\text { obtained from the Creative Commons 1.0 Statistics }\end{array}$ & 84,890 & 216,500 & 158,210 \\
Generator web site) & & &
\end{tabular}

Table III.

Open access indicators

Source: ${ }^{a}$ www.ccestadisticas.negociosabiertos.com/index.php (accessed December 2007) 
Hélio Kuramoto (IBICT) has helped to formulate a proposed law (introduced by Rodrigo Rollemberg, Member of Brazil's House of Representatives) that would require all Brazil's public institutions of higher education and research units to create OA institutional repositories of their technical-scientific output (www.camara.gov.br/sileg/ integras/461698.pdf). In this sense, Brazil is the first country in Latin America to have a Parliament bill related to the open access movement. The fundamentals of this bill are found on many declarations undersigned in Brazil to support open access, among them the one issued by IBICT at the 57th Annual Meeting of the Sociedade Brasileira para o Progresso da Ciencia (http://ibict.br/openaccess/arquivos/manifesto.htm) and also the declaration approved at an international conference at Salvador (Bahia), known as the Bahia Statement (www.icm19.org/public/documents/pdf/pt/Dcl-Salvador).

Another equally important initiative on open access in Brazil is OASIS.Br. OASIS stands for Open Access and Scholarly Information System, and it is the Brazilian portal of open access journals and repositories. Its 109 digital repositories can be searched simultaneously through a single interface by means of the OAI-PMH (Open Archives Initiative for Metadata Harvesting) protocol. The portal focuses on four main objectives: to increase the visibility of the Brazilian scientific production; to ease the access to information through a single site; to act as metadata service provider, and to support the open access movement in Brazil and worldwide.

\section{Chile}

Among the countries surveyed, Chile has the highest DOI in Latin America, reaching 0.57. Chile was the second country to implement and adapt creative common licenses to local legislation in the region since July 2005. So far, 158,210 licenses have been already granted. Regarding its scientific output, Chile stands in the third position, showing a production registered in ISI of about 3,400 documents:

- The Consejo Nacional de Rectores de Universidades Chillenas (CRUCH) and the Comisión Nacional de Ciencia y Tecnología (Conicyt) have developed a National Plan of Access to Scientific and Technical Information to serve universities and other public and private research institutions.

CINCEL is a private law corporation established by CRUCH and Conicyt, engaged in building a National Electronic Library, and managing acquisition and access to a range of scientific and technical journals to be equally available to all participating institutions. A clause has been added recently compelling publishers to allow downloads of all national scientific literature, in order to be made available at public repositories. These are considered to be an important part of the plan, which is still under development.

Chile is represented in international open access directories, such as ROAR and Directory of Open Access Repositories (DOAR) by five open access repositories:

- Two at Universidad de Chile: Cybertesis and Captura. Cybertesis hosts doctoral theses, and its name is related to the software upon which it is built; Captura hosts journal articles, theses and other document types.

- One at Universidad de Talca, which hosts Memoirs and other document types.

- One at Universidad del Bío Bío, with doctoral theses.

- SciELO Chile is registered as an open access journals repository.
Open access indicators 
OCLC

25,2
As it can be observed, doctoral theses and journal articles count among the most visible Chilean electronic documents accessible through the internet.

A significant step in favour of the open access movement was the Valparaíso Statement for the improvement of scientific communication in the electronic environment, held in Valparaíso in January 2004. The statement stresses the need to use the internet as the most efficient tool for the immediate dissemination of knowledge, and it declares that journal publishers are responsible for their maximum visibility and availability at various repositories.

\section{Argentina}

Considering the DOI and the Information Society Growth, Argentina appears in tenth place showing a growth of 4 per cent. In ROAR, this country is represented only by two repositories: SciELO Argentina, and a journal published by the public university, Universidad Nacional del Centro, since both of them are harvested through the OAI protocol. There are several other repositories and/or digital libraries in the country, mainly within public universities, all of which have started collecting electronic theses. Examples are Universidad Nacional de Cuyo, Instituto Balseiro, which belongs to the same university, Universidad Nacional de La Plata and the Latin American Counsil on Social Sciences (Spanish acronym, CLACSO) (www.clacso.org.ar/). CLACSO is an international NGO associated to UNESCO, created in 1967. It brings together about 170 research centers distributed across 21 countries in Latin America and the Caribbean. Since 2004 CLACSO digital library activities has been supported by INASP (International Network for the Availability of Scientific Publications) (www.inasp. info/). As of now, it hosts over 9,000 full-text documents.

In total, Argentina has seven institutional repositories, though not OAI compliant yet. The Directory of Open Access Journal (www.doaj.org/) registers 42 electronic journals from Argentina, and the SciELO Argentina repository, 29. There are no public policies or mandates related to open access; still, there is growing concern to promote its benefits, especially among the librarian community.

Regarding the creative commons licenses, many have been adapted to legal local frameworks since October 2005, and statistics observed at Negocios Abiertos web site (www.negociosabiertos.com/) show that around 85,000 licenses were granted.

Regarding the scientific output, Argentina is the second of the three selected countries, producing around 5,900 documents/year. Nonetheless, the number of registries per repository is very low, about 2,200, far from the other two countries. Argentina's visibility level is the lowest of the region.

\section{Conclusions}

In terms of scientific output vs investment level in science and technology, Brazil stands out in first place, followed by Chile and Argentina, respectively. The same relation applies to visibility on the web: Brazil stands in the first place, Chile is second, and Argentina is in the last place.

Additionally, the DOI shows that Chile is in the best position considering levels of inclusion in the Information Society in Latin America, even over several European countries. Brazil is in the second place, followed by Argentina.

As far as the legal framework is concerned, Brazil was the first country of the three to adapt $\mathrm{CC}$ licenses to local legislation, followed by Chile in the second place, and 
Argentina in the last position. Brazil is also the first country in Latin America with a bill in Parliament in favour of the open access movement, a major step even considering the international context.

In terms of document types, electronic theses and $\mathrm{OA}$ journals are the most widely represented from the late 1990s both Brazil and Chile have engaged in electronic theses programs, taking advantage of the support offered by UNESCO. A number of repositories in Chile started as electronic theses repositories.

Finally, from many perspectives, Brazil is the country that epitomizes the concept underlying the open access movement: publicly funded research should be available free of charge to anyone. In this way, the SciELO platform has been a key opportunity to launch the open access initiative in Latin America, joined by Chile in 1998, and by Argentina several years later.

Digital repositories in these three countries are slowly catching up with the concept of access to research supported and financed by government and other public agencies. They are essential to help bridge the south-north digital divide, that is often ignored by developed countries (Kirsop et al., 2007).

\section{References}

BOAI (2005), Budapest Open Access Initiative, available at: www.soros.org/openaccess/ (accessed November).

Chan, L. and Costa, S. (2004), "Participation in the global knowledge commons: challenges and opportunities for research dissemination in developing countries", E prints in Library and Information Science E Lis, available at: http://eprints.rclis.org/archive/00002611/ (accessed November).

Costa, S. (2007), "New publishing models for scholarly communication and the Brazilian open access policy", paper presented at PKP Scholarly Publishing Conference Blog, available at: http://scholarlypublishing.blogspot.com/search/label/Brazil (accessed December).

Costa, S. and Kuramoto, H. (2007), "New publishing models for scholarly communication and the Brazilian open access policy", paper presented at 1st PKP Conference, Vancouver, July 2007, available at: http://pkp.sfu.ca/ocs/pkp2007/index.php/pkp/1/paper/view/63/82 (accessed December).

Electronic Publishing Trust for Development (2007), "Brazilian OAI", November 12, 2007, available at: http://epublishingtrust.blogspot.com/2007/11/oa in brazil.html (accessed December).

International Communication Union (2007), World Information Society Report 2007: Beyond WSIS, 2nd ed., available at: www.itu.int/osg/spu/publications/worldinformationsociety/ 2007/

Kirsop, B., Arunachalam, S. and Chan, L. (2007), "Access to scientific knowledge for sustainable development: options for developing countries", Ariadne, Vol. 52, available at: www. ariadne.ac.uk/issue52/kirsop et al/ (accessed October).

Observatorio para la Sociedad de la Información en América Latina y el Caribe (2007), "Monitoreo del eLAC 2007: avances y estado actual del desarrollo de las Sociedad de la Información en América Latina y el Caribe", available at: www.eclac.org/publicaciones/ xml/5/29945/ResumenEjecutivo.pdf (accessed December).

Organization for Economic Co operation and Development (2004), "Declaration on access to research data from public funding", available at: http://webdomino1.oecd.org/horizontal/
Open access indicators 
oecdacts.nsf/Display/2F3530C4FE5F02D7C125729C00508A9A?OpenDocument (accessed December).

Rossini, C. (2007), "The open access movement: opportunities and challenges for developing countries. Let them live in interesting times", Diplo Foundation Internet Governance Program 2007, available at: http://campus.diplomacy.edu/env/scripts/Pool/GetBin.asp? IDPool $=3737$ (accessed December).

SciELO (2007), available at: www.scielo.org/php/index.php?lang = es (accessed November).

Suber, P. (2004 2006), “Open access overview”, available at: www.earlham.edu/ peters/fos/ove rview.htm (accessed November).

Willbanks, J. (2006), “Another reason for opening access to research”, BMJ 33, available at: www. bmj.com/cgi/reprint/333/7582/1306 (accessed December).

WSIS (2006), World Summit on the Information Society, available at: www.itu.int/wsis/basic/ about.html (accessed November).

\section{Further reading}

Babini, D. and Fraga, J. (2004), "Bibliotecas virtuales para las ciencias sociales", CLACSO, Buenos Aires, available at: http://eprints.rclis.org/archive/00005185/01/intro.pdf (accessed December).

Bustos González, A. and Moya Anegón, F. (2008), "La investigación científica chilena (1990 2005)", Tesis de grado para oponer el grado de doctor en Ciencias de la Información. Dirigida por Félix de Moya y Anegón, Facultad de Bibliotecología y Documentación, Universidad de Granada, Granada.

International Communication Union (2006), The Digital Opportunity Index: A User's Guide, available at: www.itu.int./ITU D/ict/doi/material/doi guide.pdf (accessed December).

Morrison, H. (2005), "Dramatic growth of open access: revised update", available at: http:// poeticeconomics.blogspot.com/2005/08/dramatic growth of open access revised.html (accessed December).

Morrison, H. (2006), "Dramatic growth of open access: implications and opportunities for resource sharing", Journal of Interlibrary Loan, Document Delivery \& Electronic Reserve, Vol. 16 No. 3, available at: http:/ir.lib.sfu.ca/handle/1892/510 (accessed December 2007).

Moya Anegón, F. (2007), "Ciencia en América Latina, visibilidad internacional y acceso abierto", Décimo aniversario de SciELO FAPESP, Sao Paulo, Agosto 2007, available at: www. eventos.bvsalud.org/scielo10/public/documents/13h00\%20Felix \%20de\%20Moya 115353. pdf (accessed November).

Olaya, D. and Peirano, F. (2007), "El camino recorrido por América Latina en el desarrollo de indicadores para la medición de la sociedad de la información y la innovación tecnológica", Revista Iberoamericana de Ciencia Tecnología y Sociedad, Vol. 3 No. 3, pp. 153 85, available at: www.revistacts.net/3/9/09/file 